\title{
Peran Humas Mengedukasi Masyarakat Pentingnya Alat X-Smoke dalam Perubahan Iklim dan Karhutla
}

\author{
Madinatul Munawaroh \\ Program Studi Pendidikan Administrasi Perkantoran, Universitas Negeri Surabaya \\ madina.unesa@gmail.com
}

\begin{abstract}
The purpose of this study is to determine the role of public relations in educating the public about the importance of X-Smoke tools in fighting climate change and the impacts of forest and land fires and the media that can be used to support the educational process. Public relations has the most important role in an institution and is the spearhead or forefront of the institution. Public relations in carrying out its role using publication media. This research was conducted using descriptive methods. The data that has been collected from the literature review will then be used as a basis for conducting an analysis. Data analysis was performed using qualitative descriptive. The source of data obtained through a literature study is to use the object of study from books, scientific articles, journals, and literature from the internet that are relevant to the discussion of the problem. The result of this research shows that public relations have an important role in the institution, namely as an expert advisor, communication facilitator, problem-solving facilitator, and communication technician. Publication media that can be used are print, electronic and social media.
\end{abstract}

Keywords: education, the role of public relations, climate change, media publication

\begin{abstract}
Abstrak: Tujuan penelitian ini adalah untuk mengetahui peran humas mengedukasi masyarakat tentang pentingnya alat X-Smoke dalam memerangi perubahan iklim dan dampak karhutla dan media yang dapat digunakan dalam menunjang proses memberikan edukasi. Humas memiliki peranan terpenting dalam sebuah lembaga dan menjadi ujung tombak atau garda terdepan dalam lembaga. Humas dalam menjalankan peranannya menggunakan media publikasi. Penelitian ini dilakukan dengan menggunakan metode deskriptif. Data yang telah terkumpul dari hasil tinjauan pustaka selanjutnya akan digunakan sebagai pijakan dalam melakukan analisis. Analisis data dilakukan dengan menggunakan deskriptif kualitatif. Sumber data yang diperoleh melalui studi pustaka yaitu dengan menggunakan obyek kajian dari buku, artikel ilmiah, jurnal maupun literatur dari internet yang relevan dengan pembahasan masalah. Hasil penelitian dapat diketahui bahwa humas memiliki peranan penting dalam lembaga yakni sebagai penasehat ahli, fasilitator komunikasi, fasilitator pemecahan masalah dan teknisi komunikasi. Media publikasi yang dapat digunakan yakni media cetak, elektronik dan media sosial.
\end{abstract}

Kata Kunci: edukasi, peran humas, perubahan iklim, media publikasi

\section{PENDAHULUAN}

Humas (public relations) merupakan salah satu bagian yang terpenting dalam sebuah lembaga. Peran humas menjadi ujung tombak atau garda terdepan dalam lembaga dan sebagai pengolah citra yang baik dan menciptakan iklim yang kondusif serta hubungan harmonis (Rini et al., 2017). Kedudukan public relations dalam sebuah lembaga telah bergerak ke arah yang lebih dinamis yang difungsikan menjadi sebuah bagian yang penting dalam sebuah fungsi manajemen (Puspita et al., 2014). Kehadiran public relations menjadi sangat diperlukan karena humas memiliki tugas sebagai perantara atau penghubung antara lembaga dengan lingkungannya (Suratman \& Wulandari, 2017). Kerja humas untuk menyampaikan kepada masyarakat akan hal baik mengenai organisasi (Setyanto et al., 2017). Keberhasilan dan kegagalan dalam sebuah perusahaan ditentukan oleh adanya public relations yang menghubungkan antara organisasi kepada publik ataupun sebaliknya (Listiani, 2019). Bagian humas bertugas untuk memahami dan mengevaluasi berbagai opini publik atau isu publik sebagai organisasi atau lembaga dengan public (Anggarda, 2016).

Bagian humas memiliki tujuan dan fungsi yang penting dalam sebuah lembaga. Menurut (Puspita et al., 2014), humas membutuhkan fungsi yang harus dijalankan untuk mencapai tujuan-tujuan yang ingin dicapai. Terdapat tujuan internal dan eksternal humas yakni mencapai etos kerja dan 
menjalin relasi dengan pihak luar lembaga (Herlina, 2015). Bidang kehumasan di sebuah lembaga memiliki peran secara fungsional dalam menyebarluaskan maupun mempublikasikan kegiatan lembaga yang bertujuan untuk informasi kepada pihak internal maupun eksternal lembaga (Nisak \& Muhyadi, 2018). Sedangkan fungsi pokok humas menurut Irving Smith Kogan (dalam Sari \& Soegiarto, 2019) antara lain sebagai fungsi manajemen sebagai penilai, penyelaras dan perumus suatu program kerja untuk mendapatkan dukungan serta kepercayaan masyarakat.

Peranan public relations dibagi empat kategori dalam suatu organisasi menurut Dozier \& Broom (dalam Sari \& Soegiarto, 2019) yakni sebagai expert prescriber (penasehat ahli), communication fasilitator (fasilitator komunikasi) pro (public relations officer, problem solving process fasilitator (fasilitator pemecahan masalah), communication technician (teknisi komunikasi). Jenis media publikasi antara lain media cetak, elektronik, dan media sosial (Mahfuzhah \& Anshari, 2018).

Polusi kabut asap kebakaran hutan yang terjadi berkontribusi besar pada permasalahan kesehatan manusia dan emisi karbon atau masalah pemanasan global (Syaufina, 2018). Bahan bakar utama pada kebakaran hutan adalah kayu. Ketika kayu dibakar dengan membara maka melepaskan sebagian besar $\mathrm{CO}, \mathrm{CH}_{4}$ dan senyawa organik lainnya seperti partikulat (Volkova et al., 2019). Kandungan lain asap hasil pembakaran hutan sangat berbahaya. Kandungan asap bervariasi dengan jenis bahan bakar yang dibakar dan tahap pembakarannya (Yang et al., 2019), namun secara umum kandungan asap hasil pembakaran hutan terdiri dari $\mathrm{SO}_{2}, \mathrm{NOX}, \mathrm{O}_{3}, \mathrm{CO}$ dan partikulat berukuran kecil yang sangat aerodinamis. Partikel dengan diameter aerodinamis kurang dari $10 \mu \mathrm{m}$ didefinisikan sebagai PM10. sedangkan PM2.5 berdiameter aerodinamis kurang dari $2.5 \mu \mathrm{m}$ (WHO, 2018).

Konsep perancangan $\mathrm{X}$-Smoke yakni alat reduksi asap yang dapat mengubah zat-zat pencemar (khususnya CO, PM10 dan PM2.5) menjadi $\mathrm{CO}_{2}$ dan PM10 serta PM2.5 yang akan terbakar hingga hilang. Sebelumnya, telah dilakukan penelitian terkait reduksi emisi gas buang dengan rekayasa pemasangan catalytic converter yang ditujukan untuk mesin diesel (Vembathu Rajesh et al., 2020). Hasil yang didapat cukup bagus karena catalitic converter tersebut mampu mengurangi polutan berbahaya dengan lebih efisien dan dengan biaya lebih rendah. Penelitian lain yang serupa adalah penelitian berjudul "Application of copper-zinc metal as a catalytic converter in the motorcycle muffler to reduce the exhaust emissions" (Chafidz et al., 2018). Penelitian menunjukkan penggunaan katalis dapat menurunkan emisi gas buang jauh lebih signifikan daripada tanpa katalis.

Prinsip kerja alat dimulai dari kipas yang berputar kemudian menghisap asap masuk kedalam alat. Asap yang telah masuk akan berada pada ruang catalitic converter yang telah tersekat oleh wiremesh dan glass wool atau serat keramik yang biasa digunakan untuk insulasi suhu tinggi dan stabil hingga suhu $1600^{\circ} \mathrm{C}$ (Houston \& Clyne, 2020). Asap kemudian akan tersaring dan menempel pada serat keramik.. Prinsip kerja reduksi PM seperti prinsip kerja pada diesel particulate filters yang bekerja sebagai filtrasi PM (Orihuela et al., 2018). Reaksi yang terjadi pada catalytic converter: $\mathrm{CO}=\mathrm{CO}_{2} ; \mathrm{HC}$ $=\mathrm{H}_{2} \mathrm{O}+\mathrm{CO}_{2} ; \mathrm{NO}=\mathrm{N}_{2}+\mathrm{O}_{2}$ (Mantripragada \& Rubin, 2013). Setelah reaksi reduksi terjadi, asap yang keluar memiliki potensi lebih sedikit dan aman untuk lingkungan. Katalis akan menurunkan energi aktivasi sehingga oksidasi $\mathrm{CO}+1 / 2 \mathrm{O} 2$ menjadi $\mathrm{CO}_{2}$ akan lebih cepat tercapai pada suhu yang lebih rendah, yaitu $\left(250{ }^{\circ} \mathrm{C}-300^{\circ} \mathrm{C}\right.$ ) (Dan et al., 2014). Sementara itu menurut Heywood, oksidasi $\mathrm{CO}+1 / 2$ $\mathrm{O}_{2}$ menjadi $\mathrm{CO}_{2}$ pada fase tanpa katalis akan terjadi pada suhu $700^{\circ} \mathrm{C}$ (Cholilulloh, 2014).

Penelitian terdahulu yang dilakukan oleh (Listiani, 2019) berjudul "Peran Public Relations untuk Meningkatkan Eksistensi Perusahaan melalui Penggunaan Virtual Office di Surabaya”. Hasil penelitian menunjukkan bahwa praktisi public relations PT Otak Kanan telah melaksanakan peran sebagai public relations dengan baik melalui penggunaan virtual office, yaitu peran sebagai penasehat ahli, peran sebagai fasilitator komunikasi, peran sebagai pemecah masalah, serta peran sebagai teknisi komunikasi. Penelitian selanjutnya yang dilakukan oleh (Rini et al., 2017) berjudul "Peran Humas 
dalam Meningkatkan Citra Universitas Tribhuwana Tunggadewi". Hasil penelitian ini menunjukkan bahwa peran public relations dalam mempertahankan citra pada Universitas Tribhuwana Tunggadewi Malang adalah dengan cara memperbaiki dari dalam secara internal maupun dari luar ekternal. Penelitian (Setyanto et al., 2017) berjudul "Branding yang Dilakukan Humas pada Perguruan Tinggi Swasta". Hasil penelitian ini menunjukkan bahwa branding pada perguruan tinggi swasta perlu dilakukan dalam rangka memperkuat reputasi yang dibentuk melalui kinerja yang baik dan Humas berperan dalam upaya branding tersebut.

Adapun tujuan penelitian ini ialah untuk mendeskripsikan peran humas dalam menyebarluaskan informasi terkait pentingnya alat X-Smoke ini untuk kebaikan masyarakat yang berdampak langsung dengan polusi asap didaerah karhutla.

\section{METODE PENELITIAN}

Penelitian ini dilakukan dengan menggunakan metode deskriptif. Desain deskriptif kualitatif digunakan untuk mendapatkan gambaran yang jelas, obyektif, sistematis dan akurat tentang fakta sebenarnya dari data yang digunakan. Adapun pengertian kualitatif ialah suatu pendekatan penelitian yang menerangkan situasi tertentu dengan mendeskripsikan kenyataan berdasarkan teknik pengumpulan dan analisis data yang relevan yang diperoleh dari situasi alamiah (Rahmatillah \& Ruslan, 2017). Metode deskriptif meliputi studi literatur untuk mencari referensi peran humas dalam mengedukasi masyarakat. Data yang telah terkumpul dari hasil tinjauan pustaka selanjutnya akan digunakan sebagai pijakan dalam melakukan analisis. Analisis data dilakukan dengan menggunakan deskriptif kualitatif.

Sumber data yang diperoleh melalui studi pustaka yaitu dengan menggunakan obyek kajian dari buku, artikel ilmiah, jurnal maupun literatur dari internet yang relevan dengan pembahasan masalah.

\section{HASIL DAN PEMBAHASAN}

\section{Peran Humas dalam Memberikan Edukasi kepada Masyarakat}

Peran humas dibagi empat kategori dalam suatu organisasi menurut Dozier \& Broom yaitu expert prescriber (penasehat ahli), communication fasilitator (fasilitator komunikasi) pro (public relations officer), problem solving process fasilitator (fasilitator pemecahan masalah), communication technician (teknisi komunikasi). Sedangkan menurut (Fajri, 2017) peran humas mampu menyusun strategi-strategi yang tepat untuk dalam meningkatkan loyalitas stakeholders, baik dari segi pengelolaan organisasi sendiri, komunikasi yang dijalankan, dan pengelolaan media komunikasinya.

Berikut adalah peran humas yang merujuk dengan teori konstektual dari Dozier \& Broom yaitu:

1) Penasehat ahli

Dapat mendefinisikan masalah, menyarankan pilihan dan memantau implementasi kebijakan. Peran humas sebagai penasehat ahli atau pemberi solusi terhadap suatu permasalahan dengan publiknya. Humas memberikan masukan kepada pimpinan lembaga pada saat terjadi suatu topik permasalahan. Dalam diskusi rapat dengan berbagai ahli dalam merealiasikan publikasi alat XSmoke dikalangan masyarakat, humas berperan untuk memberikan solusi yang tepat mengenai bagaimana alur publikasinya serta media yang digunakan. Sehingga dapat publikasi dapat dijalankan dengan baik untuk sekarang dan kedepannya.

2) Fasilitator komunikasi 
Bertugas untuk menjaga hubungan dan komunikasi dua arah. Peran humas sebagai fasilitator komunikasi dalam sebuah lembaga yaitu melaksanakan tugasnya sebagai komunikator atau penghubung dalam menyampaikan informasi dengan berbagai pendekatan dan kegiatan. Pendekatan yang dilakukan adalah dengan menjalin keakraban dengan masyarakat contohnya, sehingga antara masyarakat dengan humas dalam menjalankan edukasi pentingnya alat X-Smoke dengan masyarakat luas, sehingga tidak ada batasan yang nantinya akan memudahkan dalam melakukan komunikasi satu sama lain.

3) Fasilitator pemecahan masalah

Peran humas dapat mengidentifikasi dan memecahkan masalah apabila terjadi suatu masalah antara lembaga dengan publiknya. Disini humas dapat mendengarkan keinginan atau aspirasi masyarakat. Peran aktif humas sebagai pemecah masalah dapat sangat membantu untuk mengetahui yang dibutuhkan masyarakat dalam proses memberikan pemahaman tentang pentingnya alat X-Smoke sebagai alat reduksi polusi asap karhutla akibat dari pasca kebakaran hutan.

4) Teknisi komunikasi

Media komunikasi yang digunakan humas dalam penyampaian informasinya dari lembaga ke publik/masyarakat, media yang digunakan dapat melalui whatsapp, line, telepon, handphone, $e$ mail, media sosial, dan website. Sedangkan dari pihak publik/masyarakat ke lembaga dapat menggunakan whatsapp, dan e-mail dan nomor call center. Hal ini bermanfaat untuk menyukseskan dalam proses memberikan edukasi kepada masyarakat.

\section{Media Publikasi yang Dapat Digunakan}

Media publikasi yang dapat digunakan dalam humas (Mahfuzhah \& Anshari, 2018) yaitu dapat berupa media cetak, elektronik, dan media sosial. Dalam menyukseskan dalam memberikan edukasi kepada masyarakat tentang pentingnya alat X-Smoke dalam memerangi perubahan iklim dan dampak karhutla, humas dapat menggunakan media antara lain sebagai berikut:

1. Media Cetak

Media cetak yang dapat digunakan berupa media cetak koran, pamflet, serta poster yang menarik.

Media cetak ini dapat langsung diberikan kepada masyarakat dalam rangka sosialisasi pentingnya $\mathrm{X}$-Smoke serta dapat ditempel ditempat publik seperti halte, mall, swalayan, pasar.

2. Media Eletronik

Media eletronik dari televisi yakni berupa iklan layanan masyarakat yang didalamnya berisi animasi yang memuat informasi dan edukasi mengenai alat X-Smoke yang penanyangannya selama 3 jam sekali. Sedangkan radio juga berupa iklan sama seperti di televisi, tetapi perbedaanya di radio memuat efek suara yang menarik. Keduanya bekerjasama dengan berbagai pihak swasta maupun nasional.

3. Media Sosial

Aplikasi media sosial seperti Facebook, Twitter, Instagram yang sering digunakan masyarakat khususnya kaum milenial. Media sosial ini dalam penyampainnya kepada masyarakat berupa infografis yang tertata dilaman resmi sehingga masyarakat dapat secara langsung melihat dan memahami tentang informasi yang disampaikan. Tentunya menggunakan media sosial ini harus menarik dari segi desain infografisnya dan informatif.

\section{KESIMPULAN}

Simpulan dari pembahasan diatas yaitu peran humas dalam menyukseskan edukasi kepada masyarakat mengenai alat X-Smoke ada 4 yakni penasehat ahli, fasilitator komunikasi, fasilitator 
JISIP: Jurnal Ilmu Sosial dan Ilmu Politik

ISSN. 2442-6962

Vol. 8 No. 3 (2019)

pemecahan masalah, teknisi komunikasi. Selain itu media yang dapat digunakan dalam mendukung proses edukasi yakni menggunakan media cetak berupa pamflet, poster maupun koran. Media elektronik berupa iklan layanan masyarakat di televisi dan radio, serta media sosial Facebook, Twitter, Instagram.

Saran untuk pengimplementasian peran humas ini adalah kerjasama dari berbagai pihak, terutama pemerintah pusat, daerah, mau pun masyarakat setempat dan pihak-pihak ahli teknik informatika dan desain.

\section{DAFTAR PUSTAKA}

Anggarda, A. A. (2016). Peran Humas Pemerintah Kota Surabaya Dalam Membangun Citra Bangga Surabaya Achmad Aufa Anggarda Email:

Chafidz, A., Megawati, Widyastuti, C. R., Augustia, V., Nisa, K., \& Ratnaningrum. (2018). Application of copper-zinc metal as a catalytic converter in the motorcycle muffler to reduce the exhaust emissions. IOP Conference Series: Earth and Environmental Science, 167, 12014. https://doi.org/10.1088/1755-1315/167/1/012014

Cholilulloh, M. S. (2014). Pengaruh Metallic Catalytic Converter Tembaga Berlapis Krom Dan Air Induction System (Ais) Terhadap Reduksi Emisi Gas Buang Yamaha New Jupiter Mx. Jurnal Pendidikan Teknik Mesin UNESA, 3(02), 249111.

Dan, C. O., Industri, L., Nebath, E., Pang, D., \& Wuwung, J. O. (2014). Rancang Bangun Alat Pengukur Gas Berbahaya.

Fajri, C. (2017). PERAN HUMAS DALAM MENINGKATKAN LOYALITAS STAKEHOLDERS.

Herlina, S. (2015). Strategi komunikasi humas dalam membentuk citra pemerintahan di kota malang. 4(3), 493-500.

Houston, A. J., \& Clyne, T. W. (2020). Highly porous hybrid particle-fibre ceramic composite materials for use as diesel particulate filters. Journal of the European Ceramic Society, 40(2), 542-551. https://doi.org/https://doi.org/10.1016/j.jeurceramsoc.2019.07.039

Listiani, A. F. \& J. N. (2019). Peran Public Relations untuk Meningkatkan Eksistensi Perusahaan Melalui Penggunaan Virtual Office Di Surabaya Arum Fitri Listiani Jaka Nugraha. 135-143.

Mahfuzhah \& Anshari. (2018). Media publikasi humas dalam pendidikan. 2, 137-149.

Mantripragada, H. C., \& Rubin, E. S. (2013). Chemical Looping for Pre-combustion CO 2 Capture Performance and Cost Analysis. Energy Procedia, 37(Clc), 618-625. https://doi.org/10.1016/j.egypro.2013.05.149

Nisak \& Muhyadi. (2018). Peran Humas Dalam Rangka Meningkatkan Citra Positif Lembaga Kepolisian di Polda DIY. 421, 421-428.

Orihuela, M. P., Gómez-Martín, A., Miceli, P., Becerra, J. A., Chacartegui, R., \& Fino, D. (2018). Experimental measurement of the filtration efficiency and pressure drop of wall-flow diesel particulate filters (DPF) made of biomorphic Silicon Carbide using laboratory generated particles. Applied Thermal Engineering, 131, 41-53. https://doi.org/https://doi.org/10.1016/j.applthermaleng.2017.11.149

Puspita, Y., Lestari, Y., \& Marta, R. (2014). PERAN HUMAS DALAM MENINGKATKAN. 266-272. Rahmatillah, Ruslan, H. H. (2017). 済無No Title No Title. Journal of Chemical Information and 
JISIP: Jurnal Ilmu Sosial dan Ilmu Politik

ISSN. 2442-6962

Vol. 8 No. 3 (2019)

Modeling, 53(9), 1689-1699.

Rini, K. S., Rusmiwari, S., Widodo, H. P., Studi, P., Komunikasi, I., \& Tunggadewi, U. T. (2017). Peran humas dalam meningkatkan citra universitas tribhuwana tunggadewi. 6(1), 34-37.

Sari, W. P. ;, \& Soegiarto, A. (2019). FUNGSI DAN PERAN HUMAS DI LEMBAGA PENDIDIKAN. $47-64$.

Setyanto, Y., Anggarina, P. T., \& Valentina, A. (2017). Branding yang Dilakukan Humas pada Perguruan Tinggi Swasta. 171-182.

Suratman \& Wulandari. (2017). Public Relations Talents of PR. Salemba Humanika.

Syaufina, L. (2018). Chapter 8 - Forest and Land Fires in Indonesia: Assessment and Mitigation (P. Samui, D. Kim, \& C. B. T.-I. D. S. and M. Ghosh (eds.); pp. 109-121). Elsevier. https://doi.org/https://doi.org/10.1016/B978-0-12-812056-9.00008-7

Vembathu Rajesh, A., Mathalai Sundaram, C., Sivaganesan, V., Nagarajan, B., \& Harikishore, S. (2020). Emission reduction techniques in CI engine with catalytic converter. Materials Today: Proceedings, 21, 98-103. https://doi.org/https://doi.org/10.1016/j.matpr.2019.05.369

Volkova, L., Roxburgh, S. H., Surawski, N. C., Meyer, C. P. (Mick), \& Weston, C. J. (2019). Improving reporting of national greenhouse gas emissions from forest fires for emission reduction benefits: An example from Australia. Environmental Science \& Policy, 94, 49-62. https://doi.org/https://doi.org/10.1016/j.envsci.2018.12.023

WHO. (2018). Ambient (outdoor) air quality and health.

Yang, X., Ma, Y., Wang, G., Alvarado, E. C., Tigabu, M., Ju, Y., \& Guo, F. (2019). Characterization of pollutants emitted during burning of eight main tree species in subtropical China. $\begin{array}{llll}\text { Atmospheric } & \text { Environment, } & 216899 .\end{array}$ https://doi.org/https://doi.org/10.1016/j.atmosenv.2019.116899 